『еорія ј практика

міжЗародного права

\section{An attempt of defining Ethnic Minorities for their better protection}

\begin{abstract}
Although the problem of defining ethnic (national) minorities has been written in a lot, it has not been resolved to this day. In that respect, after pointing out that it is more correct to speak about ethnic minorities than national minorities, the article gives an overview of the most important attempts to give an abstract definition of ethnic minorities, which would apply to all cases. Noting that there is still no generally accepted definition of these groups, the article offers explanation of why this is so. After that nine characteristics of ethnic minorities are identified, with the belief that they are at the same time the most important elements for defining these groups. The article points out that various definitions are possible, for various needs. Then a comprehensive general (abstract) definition of ethnic minorities is offered with the belief that it he can serve in most cases.
\end{abstract}

Keywords: National Minorities, Human Rights, International Law, Comparative Law

Хоча про проблему визначення етнічних (національних) меншин написано багато, вона не вирішена і до сьогодні. У цьому відношенні, зазначивши, що говорити про етнічні меншини правильніше, аніж про національні меншини, автори статті дають огляд найважливіших спроб дати абстрактне визначення етнічних меншин, яке б могло застосовуватись до усіх можливих випадків. Відзначаючи, що досі немає загальновизнаного визначення цих груп, автори статті пропонуєть пояснення, чому це так. Після цього визначають дев'ять характеристик етнічних меншин, вважаючи, що вони водночас $є$ найважливішими елементами для визначення цих груп. У статті зазначається, що можливі різні визначення для різних потреб. На завершення пропонується вичерпне загальне (абстрактне) визначення етнічних меншин, що може застосовуватись у більшості випадків.

Ключові слова: національні меншини, права людини, міжнародне право, порівняльне право

\title{
INTRODUCTION
}

Among various minorities, for historical, political, legal and other reasons of particular interest are to those commonly referred to as national or ethnic. Their protection is important not only from the point of view of enabling the enjoyment of individual and collective minority rights, ${ }^{1}$ and in relation to avoiding ethnic conflicts

1 History teaches us that along with religious, ethnic minorities are most often actual or potential victims of genocide. This is why the Convention on the Prevention and Punishment of the Crime of Genocide (1948) defining that crime in the art 2, specifies that "genocide means any of the following acts committed with intent to destroy, in whole or in part, a national, ethnical, racial or religious group, as such..." After all, the UN Secretary-General Kofi Annan found necessary to underline: "We must protect especially the rights of minorities, since they are genocide's most frequent targets". ANNAN, K. Genocide is Threat to Peace Requiring Strong, United Action, Secretary-General Tells Stocholm International Forum, United Nations, SG/SM/9126/REV.1, 11 February 2004. [online]. [2018-10-30]. Available at: <www.un.org/ press/en/2004/sgsm9126Rev1.doc.htm>). On the connection between ethnic diversity and violence, including cases for the past 220 years see: HOROWITZ, D. L. The Deadly Ethnic Riot. Berkeley: University of California Press, 2001.

УДК: 341.231 .14

https://doi.org/10.36952/uail.2020.3.26-40

() B. Krivokapić (C) E. Sałkiewicz-Munnerlyn
KRIVOKAPIĆ Boris

LL.D., Full Professor, Busines and Law Faculty, University 'Union - Nikola

Tesla', Belgrade, Serbia

SAŁKIEWICZ-MUNNERLYN Ewa

LL.D, lecturer at Akademia Krakowska AFM, Krakow, Poland 
and ensuring tolerance, social harmony and true democracy in countries, ${ }^{1}$ but also internationally, primarily in interstate relations, ${ }^{2}$ and, with all that, from the point of view of legal science, that is as a theoretical issue of great significance. A particular problem is the fact that, although the protection of these collectives is getting better and being more complete, especially in Europe, there is no widely accepted definition. Therefore, the question arises as to how to reliably know to whom the guaranteed minority rights apply, who is their titular. Or in other words, who has the right to call upon them and asks them to be recognized and secured.

International law does not contain a specific requirement that ethnic (national) minorities be defined, such as, for example, is provided for by Article 5/2 of the genuine text of the Rome Statute (1998) regarding the crime of aggression under the jurisdiction of the International Criminal Court. ${ }^{3}$ However, the mentioned case is an exception that confirms the rule that international law does not by itself require the compulsory definition of its terms, concepts and institutes. However, this definition is necessary by the logic of the matter, because only when there is a definition established by a relevant international agreement can it be reliably known what exactly is all about. Even when there is such a binding definition, various interpretations of its elements are possible, and without it, international treaties, even when of very high quality, can often not be fully applied, because it remains controversial to whom and to what their solutions relate.

This is the reason why international crimes are defined by the statutes of international criminal courts ${ }^{4}$ or by international treaties that provide for their prevention and punishment. ${ }^{5}$ However, in

1 BARTH, F. ed. (1969): Ethnic Groups and Boundaries. Boston: Little, Brown and Company, 1969; CONNOR, W. NationBuilding or Nation-Destroying?. World Politics. 1972, Vol. 24, № 3, pp. 319-355; HOROWITZ, D.L. Ethnic groups in Conflict. Berkeley: University of California Press, 1985; KAUFMANN, C. Possible and Impossible Solutions to Ethnic Civil Wars., International Security. 1996, Vol. 20, No 4, pp. 136-175; TURTON, D., FERRERAS, J.G. eds. Cultural Identities and Ethnic Minorities in Europe. Bilbao: Univesidad de Deusto, 1999; SMOOHA, S. The Model of Ethnic Democracy. ECMI Working Paper No 13. [online] 2001 [2018-11-02]. Available at: <www.ecmi.de/uploads/tx_lfpubdb/working paper_13.pdf $>$; WHEATLEY, S. Deliberative Democracy and Minorities. European Journal of International Law. 2003, Vol. 14, No 3, pp. 507-527; KYMLICKA, W. Multicultural Citizenship: A Liberal Theory of Minority Rights. Oxford: Oxford University Press, 2004; MALLOY, T.H., OSIPOV, A., VIZI, B. eds. Managing Diversity Through Non-Territorial Autonomy. Oxford: Oxford University Press, 2015.

2 National minorities can be a bridge that connects states, speeds up integration processes among them, and the like, but they can also be an apple of discord. This last, even when the position of the minority concerned is not bad at all. An example is what Hitler did when he falsely claimed that the German minority in the Sudeten region was subjected to persecution. He threatened to wage the war in order to protect allegedly endangered compatriots. By this he managed to achieve conclusion of the Munich Agreement (1938) by which the Region was seized from Czechoslovakia and merged with Germany (if fact, that was Hitler's true goal).

On various aspects of relationship between the existence and position of ethnic (national) minorities and international relations and international law: MACARTNEY, C.A. National States and National Minorities. New York, Oxford University Press, 1934, pp. 157-423; DE SILVA, K.M., MAY, R.J., eds. Internationalisation of Ethnic Conflict. London: Pinter Publishers, 1991; BROWN, M.E. ed. Ethnic Conflict and International Security. Princeton: Princeton University Press, 1993; GRIFFITHS, S.I. Nationalism and Ethnic Conflict: Threat to European Security. Oxford: Oxford University Press, 1993; JACKSON PREECE, J. National Minority Rights vs. State Sovereignty in Europe: Changing Norms in International Relations? Nations and Nationalism. 1997, Vol. 3, No 3, pp. 345-364; DAVIS, D.R., MOORE, W.H. Ethnicity Matters: Transnational Ethnic Alliances and Foreign Policy Behaviour. International Studies Quarterly. 1997, Vol. 41, No 1, pp. 171-184; STAVENHAGEN, R. Ethnic Conflicts and Their Impact on International Society. International Social Science Journal. 1998, Vol. 50, No 157, pp. 433-445; BROWN, M. et al. Nationalism and Ethnic Conflict. Cambridge MA: MIT Press, 2002, pp. 77-91; KYMLICKA, W. The Internalisation of Minority Rights. International Journal of Constitutional Law. 2008, Vol. 6, No 1, pp. 1-32; CARMENT, D. JAMES, P., TAYDAS, Z. The Internationalisation of Ethnic Conflict: State, Society, and Synthesis., International Studies Review. 2009, Vol. 11, No 1, pp. 63-86; PALERMO, F., SABANADZE, N. eds. National Minorities in Inter-state Relations. Leiden - Boston: Martinus Nijhoff, 2011; PAVKOVIĆ, A., RADAN, P. eds. The Ashgate Research Companion to Secession. Farnham: Ashgate, 2011.

3 "The Court shall exercise jurisdiction over the crime of aggression once a provision is adopted in accordance with articles 121 and 123 defining the crime and setting out the conditions under which the Court shall exercise jurisdiction with respect to this crime. Such a provision shall be consistent with the relevant provisions of the Charter of the United Nations."

4 Thus, for example Art. 6 of the Nuremberg Charter of the International Military Tribunal (1945), Art. 2-5 of the Statute of the Internatinoal Criminal Tribunal for the Former Yugoslavia (1993), Art. 2-4 of the Statute of the International Criminal Tribunal for Rwanda (1994) etc.

5 For example, definition of genocide in the Art. II of the Convention on the Prevention and Punishment of the Crime of Genocide (1948), of unlawful seizure of aircraft in Art. 11 of the Convention on Offences and Certain other Acts Committed on the Board of Aircraft (1963), of racial discrimination in the Art. 1/1 of the International Convention on the Elimination of All Forms of Racial Discrimination (1965), of piracy in the Art. 101 of the UN Convention of the Law of the Sea (1982), of torture in the Art. 1/1 of the Convention against Torture and Other Cruel, Inhuman or Degrading Treatment or Punishment (1984), of enforced disappearance in the Art. 2 of the International Convention for the Protection of All Persons from Enforced Disappearance (2006) etc. 
some cases, political reasons prevent the adoption of a definition of certain term, concept or institute. The best example is the fact that although terrorism is one of the biggest problems of the modern world and although there are a large number of international documents dealing with the fight against it, there is no generally accepted definition. This is because the states are not ready to accept a definition that would clearly determine when it comes to terrorist acts and terrorists. Without this definition, they retain the freedom of their own estimates, and therefore, often, in the same persons and groups some states see terrorists while others see freedom fighters. This, however, does not change the fact that the general binding definition of terrorism is necessary and that, sooner or later, it will be adopted

It is similar in the field of human rights. It is not enough just to establish that some categories of people have certain special rights and to provide for mechanisms for their implementation. It is necessary to precisely determine the frameworks in order to know exactly who these rights belong to. Therefore, in international treaties, definitions of refugees, stateless persons, the child, migrant workers, persons with disabilities, etc. appear. ${ }^{1}$ However, here also some important notions and institutes are not yet defined because states can not agree on what exactly is in mind, that is, they do not want to bind their own hands by precise definition. ${ }^{2}$ This is also true for the fact that, although in the international context, and especially in Europe, there has never been a better legal regulation of the position of ethnic (national) minorities, there is still no definition of them.

It is, however, necessary for several reasons:

- to ensure that States could not deny the existence of ethnic (national) minorities in their territory when those groups are objectively present;

- to ensure that States which otherwise recognize the existence of some ethnic (national) minorities would not be able to arbitrarily deny the status of ethnic minorities to certain such groups (unfortunately, a rather widespread practice);

- to ensure clear criteria as to who belongs to these groups and, therefore, to whom special minority rights recognized by international law belong;

- in order to establish sufficiently precise framework of the State's obligation to protect ethnic (national) minorities by recognizing certain reasonable limits;

- to make the distinction between ethnic (national) minorities and some similar groups, which yet have a different legal and factual position, such as above all indigenous peoples.

In our time, the conditions for the protection of ethnic (national) minorities are more favourable than ever. Among other things, this is due to the fact that this matter is regulated at the universal level by the Declaration on the Rights of Persons Belonging to National, or Ethnic, Religious and Linguistic Minorities (1992) and in Europe by the Framework Convention for the Protection of National Minorities (1995) and also by many other international documents, including more and more bilateral agreements.

However, the big problem is the fact that there is no universally accepted definition of ethnic (national) minorities, which in practice sometimes leads to situation in which protection that is guaranteed to these groups is not provided to everyone to whom it is intended and belongs.

It can be relatively quickly expected that, in view of what happened in Europe, specific conventions on the protection of ethnic (national) minorities will be adopted on other continents as well as at the universal (world) level. The reason we believe so is the fact that this is a very important issue, which is not only of a theoretical nature, but also has an expressed practical significance, since it also affects the relations within the states and in the bilateral relations of the countries concerned and in the wider international interests. At the same time the problem concerns not only human rights, but also issues of peace and security, cooperation between states and other important problems. Work on the adoption of the new documents in this field will be a new opportunity to determine the definition of ethnic (national) minorities that would apply at least in regional, and very likely in the world level.

In this paper, we will recall the basic problems related to the definition of minorities, offer our own view of the most important characteristics of ethnic minorities, and thus the elements that,

\footnotetext{
1 Art. 1 of the Convention Relating to the Status of Refugees (1951), Art. 1 of the Convention Relating to the Status of Stateless Persons (1954), Art. 1 of the Convention on the Rights of the Child (1989), Art. 1 of the International Convention on the Protection of the Rights of All Migrant Workers and Members of Their Families (1990), Art. 1/2 of the Convention on the Rights of Persons with Disabilities (2006). Some of these conventions also give official definitions of some other terms, but this is not so important here.

2 A good example is the right of peoples to self-determination, which is guaranteed already in the UN Charter (Articles $1 / 2$ and 55), art. 2 of the International Covenant on Civil and Political Rights and Art. 2. The International Covenant on Economic, Social and Cultural Rights (1966), but without a definition.
} 
in our opinion, should be contained in the definition of these groups. We shall also point out that various definitions are possible, for various needs and, finally, propose an abstract definition of ethnic minorities that we believe could b satisfactory in most cases. We believe that this is the contribution of this work.

Looking closer, taking into account the proposals that were formulated 30-40 years ago, but with the support of modern practice, including solutions of a large number of new bilateral agreements, the paper not only reminds us that this issue is still waiting to be resolved, but also offers a new approach. It starts from the fact that various definitions of ethnic (national) minorities are possible for various purposes, and that even when it comes to an abstract definition, narrow and broad definitions are acceptable, depending on the concrete circumstances. Since the abstract definition of these groups comes down to the search for a precise determination of the most important elements that describe them, the contribution of the paper is particularly reflected in the fact that compared to previous attempts to define these groups (in particular, compared to the Capotorti's definition, which is most commonly used) here we offer not only a different order of these elements, but also their far more complete list (to five in Capotorti's definition, four new ones have been added). The definition we propose is the result of almost 30 years of our dealing with the problem of protecting ethnic (national) minorities with extensive research in the fields of both international and comparative law.

\section{THE PROBLEM OF DEFINING ETHNIC MINORITIES}

Attempts to define ethnic (national) minorities ${ }^{1}$ are as old as the very dealing with this problem. They appear in doctrine, ${ }^{2}$ national legislations of the states, practice of international courts, ${ }^{3}$ etc. Yet, the most interesting ones are those contained in international documents and studies produced under the auspices

1 The terms national minorities and ethnic minorities are usually used as synonyms. However, the term national minority, strictly speaking, does not include those communities that differ in ethnic terms from the majority population, but do not form part of a nation, i.e. they do not have the kin state of their people (Roma, Kurds, Arameans, Catalans, Ashkali etc.). A better name is an ethnic minority. It has a wider reach and refers to all minority groups that differ from the majority population by ethnicity, regardless of whether they are or are not part of a nation. In other words, the national minority is always ethnic, but the ethnic minority does not always have to be national.

2 WIRTH, L. The Problem of Minority Groups, in Ralph Linton (ed.) The Science of Man in the World Crisis. New York: Columbia University Press, 1945, p. 347; HEPBURN, A.C. Minorities in History, in A.C. Hepburn (ed.) Minorities in History. London: Edward Arnold, 1978, pp. 1-3; ÅKERMARK, A. S. Justification of Minority Protection in International Law. London - The Hague - Boston, Kluwer Law International, 1997, pp. 86-98; PACKER, J. Problems in Defining Minorities, in: D. Fottrell and B. Bowring eds. Minority and Group Rights in the New Millennium. The Hague: Martinus Nijhoff Publishers, 1999, pp. 223-274; HENRARD, K. Devising and Adequate System of Minority Protection. The Hague: Martinus Nijhoff Publishers, 2000, pp. 16-55; REHMAN, J. The Weaknesses in the International Protection of Minority Rights. The Hague: Kluwer Law International, 2000, pp. 14-19; DIACONU, I. Minorities in International law., Romanian Journal of International Law. 2001, No 3-4, p. 76; PENTASSUGLIA, G. Minorities in International Law: An Introductory Study. Strasbourg: Council of Europe Publishing, 2002, p. 55; THIO, L-A. Managing Babel: The International Legal Protection of Minorities in the Twentieth Century. Leiden: Martinus Nijhoff Publishers, 2005, pp. 1-15; HANNUM, H. The Concept and Definition of Minorities, in Weller, Mark (ed.) Universal Minority Rights. Oxford: Oxford University Press, 2007, pp. 49-73; TORÓ, T. Defining the Concepts of 'Nation' and 'National Minority'. REGIO: Minorities, Politics, Society. 2007, Vol. 10, pp. 141-154; KHAN, B. U., RAHMAN, M. M. Protection of Minorities: A South Asian Discourse. Dhaka: University of Dhaka, 2009, pp. 1-13; DE VILLIERS, B. Language, Cultural and Religious Minorities: What and Who are They? University of Western Australia Law Review. 2012, Vol. 36, No 1, pp. 92-114; KHAN, B.U., RAHMAN, M.M. Protection of Minorities: Regimes, Norms and Issues in South Asia. Newcastle upon Tyne: Cambridge Scholars Publishing, 2012, pp. 1-14; VIZI, B. Protection Without Definition - Notes on the Concept of 'Minority Rights' in Europe. Minority Studies. 2013, No 15, p. 7; AFTAB, A. The Concept of 'Minority' in International law. Indian Journal of International Law. 2014, Vol. 54, pp. 92-124; GULIYEVA, G. Defining the Indefinable: A Definition of 'Minority' in EU law, in Malloy T., Marko J. eds. Minority Governance in and Beyond Europe. Brill, Nijhoff, 2014, pp. 165-198; BARTEN, U. What's in a Name? Peoples, Minorities, Indigenous Peoples, Tribal Groups and Nations, Journal of Ethnopolitics and Minority Issues in Europe. 2015, Vol. 14, No 1, pp. 1-2, 6-8; FENEMIGHO, A. I., NWAOGU, D. Defining Minorities for Adequate Protection under International Law: An Examination., Ebonyi State University Law Journal. 2016, Vol. 7, No 1, pp. 61-75.

3 This refers to the definitions given by the Permanent Court of International Justice (PCIJ) in advisory opinions The Greco-Bulgarian Communities (July 31 ${ }^{\text {st }} 1930$ ) Series B 17 pp. 19, 21-22, 33, and Minority Schools in Albania (April 6 1935) Series A/B 64 p. 17. Both documents are available online at <www.icj-cij.org/en/pcij> [2018-12-02]. 
of the United Nations (UN) ${ }^{1}$ and other international organisations. ${ }^{2}$ This, inter alia, because they take into account the complexity of reality in the international context, and due to the fact that usually behind the offered solutions there was a whole team of experts.

Among all these attempts, the most famous and most cited (though also contested) ${ }^{3}$ is the definition proposed in 1977 by the UN Special Rapporteur on the Prevention of Discrimination and Protection of Minorities, Francesco Capotorti, under which:

The term 'minority' may be taken to refer to: A group numerically inferior to the rest of the population of a State, in a non-dominant position, whose members - being nationals of the State - possess ethnic, religious or linguistic characteristics differing from those of the rest of the population and show, if only implicitly, a sense of solidarity, directed towards preserving their culture, traditions, religion or language. ${ }^{4}$

Other definitions for the needs of the UN were also offered by some other experts, ${ }^{5}$ but their proposals remained in the shadow of Capotorti's formulation, which, although not perfect, proved to be the best. This is evidenced by the simple fact that any debate about the definition of minorities begins by quoting this definition.

However, no definitions, including the one given by Capotorti, succeeded to impose itself as a generally accepted solution. After all, the definitions of minorities were offered in acts that, by their very nature, had no legal obligation or have never entered into force. ${ }^{6}$ Thus, none of the legal sources in this matter, either at the universal or at the regional level, does not provide for a legally binding definition of minorities. This despite the fact that the original intention was to include the definition of minorities in legally binding documents. What is the problem?

There are opinions that it is an 'elusive' phenomenon, and that it is objectively impossible to give a definition that would include all groups in a minority position. ${ }^{7}$ It is considered, therefore, that minorities fall into those phenomena that are popularly said to 'evade' the definition. ${ }^{8}$ The problem is also that, by nature of things,

1 Thus, for example, a definition offered in 1950 by the Subcommittee on Prevention of Discrimination and Protection of Minorities (hereinafter: SPDPM) to the UN Commission on Human Rights (hereinafter: CHR). According to it: “(a) The term minority includes only those non-dominant groups in a population which possess and wish to preserve stable ethnic, religious or linguistic traditions or characteristics markedly different from those of the rest of the population; (b) Such minorities should properly include a number of persons sufficient by themselves to develop such characteristics; and (c) The members of such minorities must be loyal to the State of which they are nationals". This proposal was not accepted, nor did the ones that the SPDPM offered later. Doc. E/CN.4/358 of 30 January 1950, p. 15, para 32/4, [2018-12-02]. Available at: <http://repository.un.org/handle/11176/259604>.

2 Rights of minorities, Recommendation 1134 (1990) Parliamentary Assembly, Council of Europe, para 11, [2018-1202]. Available at: <http://assembly.coe.int/nw/xml/XRef/Xref-XML2HTML-en.asp?fileid=15168\&lang=en>; the definition given in Art. 2. of the draft European Convention for the protection of minorities, which in 1991 was prepared by the European Commission for Democratisation Through Law (ECDTL) - CDL (1991) 007 and later proposals from the Commission - Compilation of Venice commission opinions and reports concerning the protection of national minorities, ECDTLaw (Venice commission) CDL (2011)018, Strasbourg 6 June 2011, 4, [2018-12-02]. Available at: $<$ www.venice.coe.int/webforms/documents/default.aspx?pdffile=cdl(2011)018-e>; Additional Protocol on the Rights of Minorities to the European Convention on Human Rights, Article 1, Recommendation 1201(1993) Parliamentary Assembly, Council of Europe, [2018-12-02]. Available at: <http://assembly.coe.int/nw/xml/XRef/Xref-XML2HTML-en. asp?fileid=15235\&lang=en>; An Additional Protocol to the European Convention on Human Rights on National Minorities, AS/Jur(2011)46, p. 11, para 40, [2018-12-02]. <www.assembly.coe.int/CommitteeDocs/2011/ajdoc46.pdf>; CEI Instrument for the protection of minority rights (1994), Article 1/2, Minorities and the Central European initiative, CEI 2004, p. 24, [2018-12-02]. <www.cei.int/sites/default/files/file/CEI_Publication_7_4_05.pdf>.

3 One of the weaknesses of this definition, which was acknowledged by its author himself, is the fact that it was targeted only to the application of Article 27 of the ICCPR (1966).

4 CAPOTORTI, F.: Study on the rights of persons belonging to ethnic, religious and linguistic minorities. UN 1979, Doc. E/ CN.4/Sub.2/384/Rev.1, p. 96, para 568.

5 DESCHÊNES, J. Proposal Concerning a Definition of the Term 'Minority', UN 1985. Doc. E/CN.4/Sub.2/1985/31/Corr.1, p. 30, para 181; EIDE, A. Protection of Minorities. Possible Ways and Means of Facilitating the Peaceful and Constructive Solution of Problems Involving Minorities, UN 1993, Doc. E/CN.4/Sub.2/1993/34, p. 7, para 29; CHERNICHENKO, S. Definition of minorities. Second working paper. UN 1997, Doc. E/CN4/Sub2/AC5/1997/WP1, Annex - Minorities - a working definition.

6 Various recommendations, proposals, suggestions, etc., many of which have already been mentioned.

7 After all, both in the SPDPM and in the CHR it was generally recognized that it was difficult, if not impossible, to group together under a generally satisfactory definition every minority group in need of special measures of protection. See CAPOTORTI, F.: Study on the rights of persons belonging to ethnic, religious and linguistic minorities. UN 1979, Doc. E/CN.4/Sub.2/384/Rev.1, p. 6, para 27. One can easily find such opinions even today. See REHMAN, J. The Weaknesses in the International Protection of Minority Rights. The Hague: Kluwer Law International, 2000, p. 14.

8 "There seems to be only general agreement that there is no generally agreed definition of 'minority'". THORNBERRY, P. International Law and the Rights of Minorities. Oxford: Clarendon Press 1991, p. 164. 
every definition of minorities contains a large number of legal standards or insufficiently precise terms such as 'non-dominant position', 'numerical minority', 'equality with majority', 'sense of solidarity', 'collective will for survival', 'common ethnic, cultural, religious or linguistic characteristics', 'sufficient representativeness', 'motivation to care for the preservation of one's own culture, tradition, religion or language' and the like. In practice, there is always the danger they being interpreted in various ways. ${ }^{1}$ Some authors argue that in fact it is not the task to define minorities, but to single out vulnerable groups and protect them. ${ }^{2}$ There are also those who emphasize that the acceptance of the compulsory definition would indeed be detrimental, as it would allow states to use that definition by interpreting it in ways that exclude certain groups from minority protection. ${ }^{3}$

While it is truly difficult to find a sufficiently comprehensive, flexible, yet precise definition that would satisfy everyone and cover all minority situations, it seems that the problem is, first and foremost, that states have no single view of the essence of things i.e. about who should be considered a minority. Some of them are restrictive in that respect, while others are much more liberal and willing to recognize minority rights to a wider circle of persons. ${ }^{4}$ In this way, the fact that states do not have a single position, but follow their different minority policies, prevents the establishment of a common standard. ${ }^{5}$

The need to provide sufficient manoeuvring space ${ }^{6}$ motivates some states to hinder the adoption of a definition of minorities in relevant international documents. If such a definition was adopted, the situation regarding what was considered a minority would be much clearer, which would also make it difficult for states to dodge their international legal obligations. ${ }^{7}$

1 Thus, for example, in respect to the generally simple and comprehensible standard of "numerical minority", the question can be raised of whether a numerical minority is considered in relation to the majority population or in relation to the total population of the state, whether it is a numerical minority in the whole country or on a concrete area, etc.

2 "Invisible, silent and diffuse groups are often the most vulnerable to harm... Finding vulnerable groups would replace setting on a definition of minorities." SIMON, T.W. Ethnic Identity and Minority Protection: Designation, Discrimination and Brutalization. Lanham: Lexington Books, 2012, p. 141.

3 An Additional Protocol to the European Convention on Human Rights on National Minorities, AS/Jur(2011)46, p. 11, para 42. We can not agree with this view, because it is in itself logical that, on the contrary, in the absence of binding definitions it is far easier for states to exclude certain groups from minority protection. The purpose of the definition is to prevent such developments. The impression is that those who advocate mentioned approach are consciously or unconsciously instruments of states that oppose defining, as something that would tie their hands.

4 The assessment given by Capotorti almost half a century ago is stil valid: "The official attitude towards minority groups forming part of their population can and does vary considerably. It might be said that the two extremes are represented by the case of recognition in the Constitution of the existence of a minority and the absence of any recognition at all. Between the two extremes, however, there are some middle positions: recognition on the basis of special legislation or administrative measures or the simple recognition of private institutions representing the interests of minority groups. The word "recognition" itself does not by any means always have the same meaning. It could mean that the State grants to one or minorities the status of legal persons, subjects of law, but this is very rarely encountered. It may mean that a coherent set of rights - connected with the principe of protecting the identity of minorities - is granted to members of such minorities. Sometimes, however, the only measure is the granting of some specific rights to the minorities without there being any over-all plan. In this last case, the recognition of the minority benefiting from the rights is usually implicit and partial." CAPOTORTI, F.: Study on the rights of persons belonging to ethnic, religious and linguistic minorities. UN 1979, Doc. E/CN.4/Sub.2/384/Rev.1, p. 12, paras 59-60.

5 A tragic, but good example is what happened in Rwanda. Just before the 1994 genocode Rwandan government declared to the UN Human Rights Committee that it did not have any minorities. Yet, during the 1994 genocide in Rwanda, the radical Hutus had no difficulty sorting out Tutsis from Hutus. SIMON, T. W. Ethnic Identity and Minority Protection: Designation, Discrimination and Brutalization. Lanham: Lexington Books, 2012, p. 141.

Another interesting example is France. Although beyond any doubt there are various ethnic minorities in it and even occasionally conflicts arise on that basis, that country claims that it does not have such minorities and has not yet signed the Framework Convention for the Protection of National Minorities (FCPNM, 1995). LAACHIR, K. France's 'Ethnic' Minorities and the Question of Exclusion. Mediterranean Politics. 2007, Vol. 12, No 1, pp. 99-105; MEIER, K. J., HAWES, D. P. Ethnic Conflict in France. American Review of Public Administration. 2009, Vol. 39, No 3, pp. 269-285; GILBERT, J., KEANE, D. How French Law Makes Minorities Invisible. Independent, 14 November 2016 [2018-12-02]. Available at: <www.independent.co.uk/news/world/politics/how-french-law-makes-minorities-invisible-a7416656.html>.

6 Let us remind, that the purpose of defining ethnic minorities is first of all in determining precisely who is the titular of the respective minority rights, or who is entitled to the minority protection.

7 The pragmatism of the states on this issue is borne out by the fact that, bearing in mind that this treaty does not contain the definition of national minorities, some members of the FCPNM (1995) offered their own interpretations and definitions with their reservations (Austria, Estonia, Poland, Switzerland), i.e. they specified that there were no minorities within their borders (Liechtenstein, Luxembourg, Malta), that there are only certain minorities or that the Convention will apply only to certain minorities (Germany, Denmark, FYR Macedonia, Slovenia, Sweden). Reservations and declarations for Treaty No. 157 - Framework Convention for the Protection of National Minorities, Council of Europe. [2018-12-02] Available at: <www.coe.int/en/web/conventions/full-list/-/conventions/treaty/157/declarations? auth=P7f2XZL1>. 


\section{CHARACTERISTICS OF ETHNIC MINORITIES}

Although there is no single, generally accepted definition of ethnic minorities, it appears that there is a place to point at least to certain characteristics of minorities, to some of the elements that describe them more closely and which, with a little goodwill and with the possible further upgrade, could lay the foundations of their definition.

In the legal literature, several sets of such elements are offered, starting from the simplest ones ${ }^{1}$ to those that might relate to some other minorities, and not just ethnic ones. ${ }^{2}$

Here we will not engage in the analysis of various such approaches. Instead, we will offer our view of the elements (criteria) that we believe should exist in order to call a particular group an ethnic minority.

\section{A Group of Domestic Citizens}

The requirement for minorities to be considered only domestic citizens can be found in the works of theoreticians, ${ }^{3}$ in national regulations ${ }^{4}$ and in other unilateral acts of the states. ${ }^{5}$

It is claimed that foreigners and stateless persons living in the territory of the state concerned do not belong to ethnic minorities, but their position is regulated in part by the internal regulations of the state on the legal status of foreigners, and in part with the corresponding norms of international law. ${ }^{6}$ In addition, it is noted that refugees and stateless persons, even when they have certain ethnic, religious, linguistic and similar characteristics, are usually not occupied with the effort to preserve them, but wish to assimilate. When it comes to migrant workers, it is claimed that they have come by their own will and that they can not therefore demand some special rights. It is also pointed out that the state can not take care of the special requirements of persons who are not its citizens because it means additional expenditures for persons who (unlike domestic citizens) do not owe it any loyalty in principle.

In short, regardless of the arguments presented, the attachment of minority protection to the possession of national citizenship in practice means that such protection is not recognized to foreigners.

Nevertheless, there are sufficient reasons for granting minority protection also to foreigners and stateless persons who are resident in the territory of the country concerned. This is because it is there where they work, earn money, pay taxes and other duties and, in many other ways, contribute to the building and well-being of the society in which they live. Therefore, it would be appropriate to provide them with a fuller degree of

1 Thus, the former OSCE High Commissioner on National Minorities (HCNM) has distinguished only two elements, stating that it is a group: 1) with linguistic, ethnic or cultural characteristics which distinguish it from the majority and 2) which usually not only seeks to maintain its identity but also tries to give stronger expression to this identity. VAN DER STOEL, M. Keynote Address at the CSCE Human Dimension Seminar on "Case Studies on National Minority Issues: Positive Results", Warsaw, 24 May 1993, p. 2. [2018-12-02] Available at: <www.osce.org/hcnm/38038?download=true>; VAN DER STOEL, M. Minorities, Human Rights and the International Community, Strausberg, 7 July 1995, p. 1. [2018-1202] Available at: <www.osce.org/hcnm/36591>.

2 These elements can be included in a sort of general definition, applicable to various minorities: "Any group or association of individuals that is linked by a common interest and does not comprise a majority of the population can potentially be defined as minority group. "BARTH, W. K. On Cultural Rights: The Equality of Nations and the Minority Legal Traditions. Leiden - Boston: Martinus Nijhoff Publishers, 2008, p. 38.

On the other side, some authors single out specific elements, but relating to various minority groups. Thus, according to Feagin such a group has five characteristics: (1) suffering discrimination and subordination, (2) physical and/or cultural traits that set them apart, and which are disapproved by the dominant group, (3) a shared sense of collective identity and common burdens, (4) socially shared rules about who belongs and who does not determine minority status, and (5) tendency to marry within the group. FEAGIN, J. R. Racial and Ethnic Relations. Englewood Cliffs, NJ: Prentice-Hall, 1984, p. 10.

3 Even Capotorti himself concludes that: „It is generally accepted that they (members of the minority - rem. B.K.) must be nationals of the State." See CAPOTORTI, F.: Study on the rights of persons belonging to ethnic, religious and linguistic minorities. UN 1979, Doc. E/CN.4/Sub.2/384/Rev.1, p. 96, para 566.

4 Examples are the provisions of Art. 3 of the Ukrainian Act on National Minorities (1992), Art. 1/2 of the Hungarian Act No. LXXVII on the Rights of National and Ethnic Minorities (1993), Art. 2 of the Czech Act on the Rights of National Minorities and Amendments to Some Acts (2001), Art. 1 of Moldovan Act on the Rights of National Minorities and the Legal Status of Their Organisations (2001), Art. 2/1 of the Yugoslav (today Serbian) Act on the Protection of the Rights and Freedoms of National Minorities (2002), Art. 5 of the Croatian Constitutional Act on the Rights of National Minorities (2002), Art. 3/1 of the Bosnian-Herzegovinian Act on the Protection of the Rights of Persons Belonging to National Minorities (2003), etc.

5 Thus, in their reservations to the FCPNM (1995), some states (such as Austria, Estonia, Luxembourg, Germany, Poland and Switzerland) gave their own interpretation according to which minorities are considered only domestic citizens. Reservations and declarations for Treaty No. 157 (see supra note 26).

6 By various bilateral and regional international agreements, and at the universal level, the Convention on the Legal status of Stateless Persons (1954), the Convention on the Status of Refugees (1951), the Protocol on the Legal Status of Refugees (1967), the International Convention on the Protection of the Rights of Migrant Workers and Members of Their Families (1990) and others. 
satisfaction of their special needs - to preserve their own language and customs, to have the opportunity of education in their own language, to acquire basic knowledge about their kin state, and the like.

After all, Article 27 of the International Covenant on Civil and Political Rights (ICCPR, 1966), which is still the only relevant international legal provision of universal character, does not mention the requirement of domestic citizens. ${ }^{1}$ This in spite of the fact that in some other articles the enjoyment of related rights is related to the possession of citizenship of a given state. That's why the Human Rights Committee in the point 5.2 of his General Commentary on Article 27 of the Covenant (1994) stated that persons belonging to minorities not only need not be nationals or citizens of the country concerned, but they even need not be permanent residents in it. $^{2}$

However, it should be borne in mind that the extent to which minority rights and protection will be recognized to those persons does not depend only on the good will of the territorial state, but also on objective conditions, such as the level of economic development, the state of political and other relations in society, sufficient concentration of these persons, and the like. Therefore, although it should be sought to cover by minority protection not only domestic citizens, but also foreigners living in a given country, and at least those who have permanent residence in it, these considerations are, for the time being, of little practical significance. ${ }^{3}$

\section{Residence in the Territory of the State Concerned}

The minority group (not necessarily all of it members) is supposed to have residence in the territory of the state concerned. This request is logical by itself. ${ }^{4}$

It is understood that members of ethnic minority who possess all the other required conditions (elements) retain their status as members of a minority even when they stay abroad.

\section{Possession of Ethnic, Linguistic, Religious and Similar Characteristics}

This request is least controversial. It is a legal standard in which ethnic characteristics, such as origin, customs, language, religion and the like, are taken as an example of what sets an ethnic group apart from others. In fact, exactly the effort to preserve and develop these characteristics (for example, culture) represent the very sense and meaning of the institute of minority protection.

The existence of these features is a factual matter. Although these characteristics, or at least some of them, are relatively clearly manifested (for example, a different language, religion, national costume, etc.), in practice, it may be controversial in what they consist of, or what are, among them important and why it is so, and especially do they in the given case really exist in respect for a particular group. ${ }^{5}$

1 This provision reads: "In those States in which ethnic, religious or linguistic minorities exist, persons belonging to such minorities shall not be denied the right, in community with the other members of their group, to enjoy their own culture, to profess and practise their own religion, or to use their own language."

2 "Article 27 confers rights on persons belonging to minorities which "exist" in a State party. Given the nature and scope of the rights envisaged under that article, it is not relevant to determine the degree of permanence that the term 'exist' connotes. Those rights simply are that individuals belonging to those minorities should not be denied the right, in community with members of their group, to enjoy their own culture, to practise their religion and speak their language. Just as they need not be nationals or citizens, they need not be permanent residents. Thus, migrant workers or even visitors in a State party constituting such minorities are entitled not to be denied the exercise of those rights." General comment No. 23: Article 27 (Rights of minorities), Fiftieth session (1994), para 5.2, CCPR/C/21/Rev.1/Add.5, 26. April 1994 [2018-12-02]. Available at: <http:// tbinternet.ohchr.org/_layouts/treatybodyexternal/Download.aspx?symbolno=CCPR $\% 2 \mathrm{fC} \% 2 \mathrm{f} 21 \% 2 \mathrm{fRev} .1 \%$ 2fAdd.5\&Lang=en>.

3 In a number of countries some special rights (to learn their own language, to cultivate certain forms of their own culture, etc.) are even now provided to certain foreigners (especially migrant workers and members of their families). Yet, these are not general solutions, and in any case this does not represent the recognition of related groups as ethnic minorities, meaning these groups are not entitled to a full corpus of minority rights.

4 Here it can be interesting to note that this request ("reside on the territory of that State") was included in the definition accepted in 1993 by the Council of Europe Parliamentary Assembly as a part of proposed (but not adopted) additional protocol to the European Convention on Human Rights (see supra note 8).

5 For example, during the existence of Yugoslavia, a large number of its citizens (according to the census of 1981, as much as 1.2 million) in ethnic terms declared themselves as Yugoslavs. Even more, 20 years after the breakup of Yugoslavia, population censuses in the countries that have emerged in the ruins of that country, have shown that many residents continued declaring themselves as Yugoslavs (for example, in Serbia according to the 2011 census - 23303 persons). If, at the time of the existence of Yugoslavia, they could be considered part of the majority, the disappearance of that state raised the question whether they should be treated as an ethnic minority. However, this is a much heterogeneous group that includes persons of different origins, culture, languages, religions, etc. Yet, challenging that they have common ethnic characteristics, different from the rest of the population, would lead to the conclusion that they are not ethnic minority and, therefore, do not have the right to minority protection. On the other hand, such a stand would mean disputing the very survival of this group and its members as such, and thus violating the constitutional right of citizens to declare themselves as they feel. 


\section{Real or Potential Vulnerability}

Real or potential vulnerability is the reason why one is talking about minorities and why they are being adequately protected. Protection is given not only to ensure that the concerned group will not be exposed to violence, discrimination or other unfavourable treatment, but also to create conditions in which such a group will survive, unhurriedly live and develop as such, with all its special characteristics.

While it may seem this requirement is included in the demand that the group is not in a dominant position, ${ }^{1}$ these are not the same things. The group may be in a non-dominant position, and at the same time not represent a minority, nor be compromised. This will, for example, be the case in multi-ethnic societies, where no one is an absolute majority, so it is difficult to say that some ethnic group, even when it is the most numerous, is in a dominant position. On the other hand, such a group does not represent an ethnic minority, which is especially clear when it comes to a constituent people who do not have another country (kin state) outside the boundaries of the respective country.

This requirement could also be described as a marginalised position in respect to the rest of the population, ${ }^{2}$ but that would also not be a sufficiently precise definition. Marginalisation is just one kind of real or potential vulnerability. Ethnic minorities are sometimes faced with much more serious problems, such as violence, persecution, degrading, disdain, open or disguised discrimination, and the like.

\section{Not Belonging to Indigenous People}

Although in many respects it resembles ethnic minorities, indigenous peoples (especially those who lived in the given area before the arrival of the colonisers) do not want to be treated as minorities. They struggled and managed to ensure their position be regulated by special international and internal legal documents. Therefore, ethnic minorities and indigenous peoples today are separately considered and protected. ${ }^{3}$

\section{Sufficiently Numerous Group}

The requirement of a sufficiently large group is logical in itself. ${ }^{4}$ It is unrealistic to expect that special rights are accorded to those collectives and their members who are too few.

In this connection, the question arises what exactly does mean the requirement that the group is sufficiently numerous? Is it necessary for the total number of its members to exceed a certain figure or is it more important that its relative share (percentage) in the total population is above a certain line? It is not possible to give one general answer, because in essence everything depends on the concrete circumstances. It is actually a legal standard whose contents can only be determined when applied to a specific situation. ${ }^{5}$

What is important here is the fact that there is a certain lower threshold below which the existence of a minority group is not legally relevant, since the recognition of special status to these persons would be a disproportionate burden to the society as a whole and its objective possibilities and resources. ${ }^{6}$ Where this threshold is, it is not easy to determine, but this can usually be done when all relevant circumstances related to the particular case are taken into account.

\section{Numerical Minority}

\section{It will be mentioned below.}

2 Definition: Minority, Minorities and Indigenous peoples, [online]. [2018-12-02]. Available at: <www.right-to-education. org/issue-page/marginalised-groups/minorities-and-indigenous-peoples\#section_view-default-0>.

3 See: THORNBERRY, P. International Law and the Rights of Minorities. Oxford: Clarendon Press, 1991, pp. 331-382; ANAYA, J. S. Indigenous Peoples in International Law. New York: Oxford University Press, 1996; KINGSBURY, B. 'Indigenous Peoples' in International Law: A Constructivist Approach to the Asian Controversy". American Journal of International Law. 1998, Vol. 92, № 3, pp. 414-457; WOLFRUM, R. The Protection of Indigenous Peoples in International Law. Zeitschrift für ausländisches öffentliches Recht und Völkerrecht. 1999, Vol. 59, pp. 369-382; ANAYA, J. S. International Human Rights and Indigenous Peoples: The Move Toward Multicultural State. Arizona Journal of International and Comparative Law. 2004, Vol. 21, № 1, pp. 13-61; MAZEL, O. The Evolution of Rights: Indigenous Peoples and International Law. Australian Indigenous Law Review. 2009, Vol. 13, № 1, pp. 140-158; State of the World's Indigenous Peoples. New York: United Nations, 2009; MIRANDA, L. A. Indigenous Peoples as International Lawmakers. University of Pennsylvania Journal of International Law. 2010, Vol. 32, № 4, pp. 203-263; Indigenous Peoples and the United Nations Human Rights System. New York: United Nations, 2013.

4 This request is contained also in the never adopted, but often cited Additional Protocol on the Rights of Minorities to the $E C H R$, proposed by the CoE Parliamentary Assembly by its Recommendation 1201 (1993). Its Art. 1 reads: "the expression 'national minority' refers to a group of persons in a state who... are sufficiently representative...".

5 Thus, according to Capotorti, "The Swedish Government stated 'that the concept of an ethnic or national minority in Sweden would presume that the group in question consists of at least one hundred individuals'”. CAPOTORTI, F.: Study on the rights of persons belonging to ethnic, religious and linguistic minorities. UN 1979, Doc. E/CN.4/Sub.2/384/ Rev.1, p. 9, para 38.

6 The same idea is expressed by Caporoti, who emphasized that "States should not be required to adopt special measures of protection beyond a reasonable proportionality between the effort involved and the benefit to be derived from it." CAPOTORTI, F.: Study on the rights of persons belonging to ethnic, religious and linguistic minorities. UN 1979, Doc. E/ CN.4/Sub.2/384/Rev.1, p. 96, para 566. 
The whole concept of minority protection, as, after all, its name itself, rests on the fact that the group is fewer than the rest of the population, which makes it vulnerable. In other words, numerical inferiority produces inherently weak position of minorities in relation to the majority rule. ${ }^{1}$

The question arises whether the group concerned should be less numerous than the majority (dominant) population or in relation to the total population of a country?

In countries where there is a high numerical superiority of a particular ethnic group this issue is not of great practical significance because in such a case it is precisely known who is the majority and who is the minority.

However, there are also multi-ethnic societies, those in which no ethnic group has a majority. Does this mean that there are no minorities? Of course not. In such a situation, it is only proper to observe each ethnic group in relation to the total population of the country, or in view of the degree of dominance in society.

From the above it follows that as a general solution, one can accept the view that the group should represent a numerical minority (less than 50\%) in relation to the total population of the state, but that this criterion can not always be rigorously applied. Sometimes, other moments must be taken into account, particularly due to the fact that numerically large ethnic communities can be found in minority position.

\section{Non-Dominant Position}

The purpose of minority protection is to provide the most necessary conditions for the survival and smooth development of those communities that, because of their smaller numbers, are actually or potentially vulnerable. Such a situation does not exist when the numerical minority is in a dominant position in a society. Then it has the power, and therefore the ways and means not only to protect its interests, and even to impose its will.

A minority which is in dominant position i.e. holds power, can not demand that minority protection be recognized to it. It simply does not need such protection. ${ }^{2}$

\section{Mutual Solidarity and the Will to Preserve Own Personality}

All elements of minority definition considered so far are objective, they are reduced to factual situation. To understand and define ethnic minorities, a subjective criterion is also required, which is reflected in a certain psychic attitude of the members of the group concerned towards themselves, their group and their position in society. It is reduced to the mutual solidarity of the members of the given group, their goal to achieve real and legal equality with the majority and their directly or indirectly expressed willingness to keep the group (ensure its survival) with its particularities.

Looking closer, in order to consider that there is such will (commitment), it is not necessary for members of the given group to express themselves explicitly about it. A sort of evidence in favour of such a will is the mere fact that the ethnic minority has survived over time with its characteristics. ${ }^{3}$

If, in this way, the subjective element is assumed in a certain way as soon as the existence of objective criteria is established, the question arises, why should it be discussed at all? The matter is that not all ethnic groups that have certain objective ethnic, cultural and similar characteristics, want to be treated as minorities. Some of them tend to do the opposite, to assimilate, to fully integrate into the society in which they live, that is in the majority population. In this way, the purpose of this requirement is that groups and their members who clearly show that they do not want such status are not considered ethnic minorities.

\section{Other Questions}

Sometimes the other elements stand out with the above mentioned, thus insisting on some kind of autochthonousness of the respective minorities, which tends to leave aside those groups (above all, migrant workers) that meet all other criteria, but are not 'old'enough. In other words, in such a case status of ethnic

\footnotetext{
1 "... the numerical factor (numerical inferiority as compared with the rest of the population of the State) is of an undeniable importance in view of the fact that the need to protect minorities derives essentially from the weakness of their position even within the context of a democratic State, i.e. one conforming to the model which emerges from the human rights instruments of the United Nations. In such a State, it is the will of the majority which makes the laws and determines the country's general attitude. The object of every international system for the protection of minorities has always been to ensure that the majority does not ignore the special requirements of minority groups." CAPOTORTI, F.: Study on the rights of persons belonging to ethnic, religious and linguistic minorities. UN 1979, Doc. E/CN.4/Sub.2/384/Rev.1, p. 12 , para 55.

2 On the contrary, sometimes in such situations it is necessary to protect the numerical majority from the minority. An example is what once existed in South Africa, where a white minority terrorised a huge black majority,

3 "It could rightly be argued, indeed, that when members of a population group display in their everyday life a strong sense of ethnic identity, when they persevere, sometimes against heavy odds, in the use of their language, when by their general attitude and their way of life they regard themselves and are perceived by others as belonging to a distinctive group, then it seems logical to conclude that they desire to preserve their characteristics is implicitly affirmed. Only when a group has been assimilated to the point of giving up its traditions, its customs and the use of its religion and its language, a process which could be easily and objectively evaluated, can one assume that such a group stands outside of the scope of any special measure intended to safeguard the identity of minority groups." CAPOTORTI, F.: Study on the rights of persons belonging to ethnic, religious and linguistic minorities. UN 1979, Doc. E/CN.4/Sub.2/384/Rev.1, p. 42, para 248.
} 
minorities is recognized only to those groups which live on the territory of a given state 'from ages', 'for generations', 'at least 100 years' and the like.

It is an important, complex and relatively widespread problem which various countries solve in different ways. We consider that the concept of a division and different treatment of ethnic minorities with regard to the so-called 'autochthonism' is not acceptable for several reasons. Namely, 1) it is not in accordance with contemporary international law, ${ }^{1} 2$ ) it is contrary to the very idea of minority protection, ${ }^{2} 3$ ) it is not moral, ${ }^{3}$ 4 ) it is illogical, $\left.{ }^{4} 5\right)$ it does not rest on objective criteria, ${ }^{5}$ etc. $^{6}$

\section{VARIOUS DEFINITIONS FOR VARIOUS PURPOSES}

We do believe that it is possible and even desirable to define ethnic minorities. But that does not mean that such a definition must always be the same.

In a situation where there is no single, common definition of ethnic minorities, different approaches are possible for different needs and in various frameworks.

It seems that the manner of defining minorities should depend on whether this issue is dictated by the internal needs of the respective society, whether it occurs in the bilateral relations of the states, on a regional or, ultimately, on a wider international plan.

1. Definition for the Needs of a Specific Country

For the purposes of the internal legislation and practice of certain country, it is probably the most desirable minority to be determined by the fact they are enumerated (listed) in the relevant legal act, preferably in the country's constitution. ${ }^{7}$

1 Modern International law does not limit the enjoyment of minority rights and protection only to minorities that are indigenous in the countries concerned, nor in any way encourages such practice. On the contrary, it prohibits any discrimination, which means also the one that would be implemented among certain minorities, with the motivation that some of them should have more rights because they longer than others inhabited in a given area.

2 Special rights are not given to ethnic minorities as a sort of reward for their long time presence in a given territory, but in order to ensure the survival and development of these groups with their particular language, religion, culture, etc. Minority protection is aimed at the preservation of minorities and the provision of conditions in which members of minorities will be truly equal with the majority population. There is no justification for conditioning this by the traditionalism (autochtonism) of minorities, which, after all, is most cases everyone determines and interprets the way it suits him.

3 To recognize relevant rights only to some selected minorities and deny them to groups that, except their insufficiently defined autochthonism, fulfill all other requirements (citizenship, possession of ethnic, linguistic, religious and similar characteristics, the will to preserve them, etc.) would mean to create two categories of minorities - those which are privileged (because they have special minority rights and protection) and those that are unrecognized and disenfranchised, not only in relation to the majority population, but also in relation to the recognized (autochthonous) minorities. It is particularly difficult to explain the situation which, following this concept, sometimes arises in practice, and which consists in recognizing a minority status and minority rights to an extremely small group and at the same time denying them to a significantly larger group that has all the characteristics of ethnic minorities, but which is claimed not to be autochthonous. After all, how can the right to equal legal treatment of 'new' minorities be challenged, if at the same time they are expected to be loyal citizens and, inter alia, pay taxes and other contributions, participate in political life, be subject to military duty, defend the colors of the respective country in the national sport teams, etc. All this leads us to the conclusion that the denial of minority status to 'new' minorities can not be justified either from the point of view of moral considerations.

4 In practice, some countries do not recognize as national minorities groups of several tens of thousands of members, while at the same they explicitly recognize as autochthonous minorities certain ethnic groups whose total number is only a few dozen persons.

5 The decision to classify existing minorities into autochthonous ('old') or allochthonous ('new') is usually quite arbitrary and depends on the will of a particular state, more precisely on the mood of the political structure that is at aiven moment in power. This statement remains even when the list of recognized (autochthonous) minorities is included in the constitution of the country.

6 More: KRIVOKAPIĆ, B. The problem of distinction and different treatment of 'old' (autochthonous) and 'new' (allochthonous) minorities. Polish Yearbook of International Law. 2003, Vol. XXVI, pp. 85-98

7 So, for example, arts 64-65 of the Constitution of Slovenia (1991), para 1 of the Preamble to the Constitution of Macedonia (1991), para 3 of the Preamble to the Constitution of Croatia (1991), art 61/1 of the Hungarian Law on the Rights of National and Ethnic Minorities (1993).

A special form of enumeration of who is considered a minority in a given country are unilateral declarations and reservations to the relevant multilateral treaties, something that has already been mentioned. Thus, with their reservations to the FCPNM (1995), a number of states specified to whom this document will be applied, i.e. which groups they consider national minorities on their own territory. Denmark, for example, stated that the Convention would apply to the German minority in South Jutland; Germany drew the scope of the agreement to Danes, Sorbain people, Frisians, Sinti and Roma; Slovenia to the Italian and Hungarian minorities and Roma; FYR of Macedonia to the Albanian, Turkish, Hungarian, Serbian and Roma national minorities, while Sweden stated that the national minorities in that country were Sami, Swedish Finns, Tornaders, Roma and Jews. Reservations and declarations for Treaty No. 157 (see supra note 26). 
It is also possible to give an abstract definition of minorities, but usually it is not necessary. ${ }^{1}$ It is far more important that the 'list' of minorities be complete (some minorities are not omitted) and that mechanisms for its supplements are provided (to allow it, when justified, to extend it to 'new' minorities).

\section{Defining in Bilateral Agreements}

Naming (enumeration) is the best solution for the needs of most relevant bilateral international agreements, ${ }^{2}$ and even for multilateral agreements with a very small number of members. Since there are specific groups in mind, whose minority status is not disputed between the contracting parties, here it is acceptable to avoid abstract definition as completely unnecessary. This is especially the case when, from the very name of the agreement, it can be seen on which minorities it applies. ${ }^{3}$

Nevertheless, here practice also knows the exceptions in the form of treaties that specify with specific formulations who are the beneficiaries of minority protection ${ }^{4}$ and agreements that offer some definitions of minorities, ${ }^{5}$ and even give an abstract definition of minorities. ${ }^{6}$

\section{General (Abstract) Definition for all Cases}

The question of defining ethnic minorities with a general definition that would be suitable for all cases remains open. This despite the fact that such a definition would be interesting not only from the perspective of legal science, but would be very important for practice, especially with regard to the application of universal and regional international norms and standards, because then it would be known for sure to whom they apply.

Is such a definition possible at all?

1 Still, there are such examples. Abstract definitions can be found in art $1 / 2$ of the Austrian Act on National Groups (1976), art 3 of the Ukrainian Act on National Minorities (1992), art 1/2 of the Hungarian Act on the Rights of National and Ethnic Minorities (1993), art 1 of the Moldovan Act on the Rights of National Minorities and the Legal Status of Their Organisations (2001), art 2 of the Czech Act on the Rights of National Minorities and on Amendments to Some Acts (2001), art 5 of the Croatian Constitutional Act on the Rights of National Minorities (2002), art 2/1 of the Yugoslav (Serbian) Act on the Protection of the Rights and Freedoms of National Minorities (2002), art 3 of the Bosnian-Herzegovinian Act on the Protection of the Rights of Persons Belonging to National Minorities (2003), etc.

2 Examples of regulating certain issues of the position of minorities without defining them are: Treaty between the FR of Germany and the Republic of Hungary on Friendly Cooperation and Partnership in Europe (1992), Agreement on Friendly Relations and Cooperation between the Republic of Bulgaria and the Republic of Moldova (1992), Treaty on Good Neighborly Relations, Friendship and Cooperation between Ukraine and the Republic of Moldova (1992), Treaty on Friendship and Cooperation between Romania and Croatia (1994), Treaty on Goodwill and Friendship between the Slovak Republic and the Republic of Hungary (1995) Treaty between the Republic of Hungary and Romania on Understanding, Cooperation and Good Neighborly Relations (1996), Treaty on Friendship, Good Neighborliness and Cooperation between FR Yugoslavia and Romania (1996), etc.

3 Treaty Granting Special rights to the Slovenian National Minority living in Hungary and the Hungarian National Community Living in Slovenia (1992), Agreement between the Republic of Croatia and the Republic of Hungary on the Protection of the Hungarian minority in the Republic of Croatia and the Croatian Minority in the Republic of Hungary (1997), Agreement between Serbia and Montenegro and the Republic of Hungary on the Protection of the Rights of the Hungarian National Minority living in the FR Yugoslavia and the Serbian National Minority living in the Republic of Hungary (2003), etc.

4 So, for example, art 15 of the Treaty on Good Neighborly Relations, Partnership and Cooperation between the Federal Republic of Germany and the USSR (1990) speaks of «Soviet citizens of German nationality as well as citizens who come from the Union of Soviet Socialist Republics, and are permanently settled in the Federal Republic of Germany, who want to preserve their language, culture and tradition» while art 15 of the Treaty on Mutual Understanding, Cooperation and Benefit between Romania and Albania (1994) speaks of «ethnic Romanians in Albania and ethnic Albanians in Romania».

5 So, for example, Agreement between the Federal Republic of Germany and the Republic of Poland on Good Neighborly Relations and Friendly Cooperation (1991) in art 20 defines members of the German minority in Poland as «persons who have Polish citizenship but are of German origin or opt for German language, culture and tradition» whereas in the same way members of the Polish minority in Germany are defined as «persons of German nationality, but which are of Polish origin or opt for Polish language culture and tradition «. Similarly, the Treaty between the Federal Republic of Germany and the Czech and Slovak Federal Republic on Good Neighborly Relations and Friendly Cooperation (1992) establishes in art 20 that members of the German minority in the Czech and Slovak Federal Republic are «persons who have Czech and Slovak nationality, but are of German origin, or opt for German language, culture and tradition».

6 Even in those extremely rare cases when it is given, such definition is not sufficiently precise. An example is the Agreement between the Federal Government of the FR of Yugoslavia and the Government of Romania on Cooperation in the Protection of National Minorities (2002), which in art 1 stipulates that, in accordance with that agreement, «the Romanian national minority in the Federal Republic of Yugoslavia i.e. the Serbian national minority in Romania is represent persons in their jurisdiction with a common ethnic origin, language and traditions with the majority population of the other contracting party.» One should also bear in mind that even when it does exist, each such definition is given only for the purposes of the relevant bilateral treaty and has no wider application. 
Here one has to make a difference between the principle and the actual possibility of defining. It seems that a definition could be formulated in principle, which would meet the needs of both legal science and practice. ${ }^{1}$ After all, the often quoted Capotorti's definition with possible corrections could serve quite good. Reality, however, tells us that in real terms, there is no for all acceptable definition because the pure fact that states (governments) simply do not want it.

\section{Definitions in Narrow and Wide Sense}

Is it then possible to define ethnic minorities at all? We believe it is. At the same time, at least for now, it should be accepted that various definitions are possible, for various purposes. There was already a word about that. Viewed from the essential side, not only is it acceptable, it is probably also correct to give different definitions of minorities depending on specific needs (national regulation, bilateral agreement, regional agreement, universal international agreement, international organisation act, etc.). Keeping in mind the immediate requirements of the given situation, minorities can be defined narrower or broader. Under minorities, for example, one can understand only domestic citizens (narrow definition), but, if desired, even foreigners (broader definition). After all, many social phenomena are understood and determined in a narrower and broader sense, so we do not see why this could not be done with minorities.

Determining minorities in a wider or broader sense is interesting for two reasons. Firstly, because this allows for the flexibility of minority protection and opens the way for adapting to existing circumstances. Secondly, because, even in the same document, various legal implications can be tackled for various narrower or broader definitions of minorities. Thus, for example, it is possible to recognize broader rights to minority members in a narrow sense (for example, those who are domestic citizens, among other matters) than to members of minorities in a wider sense, without denial of anyone's minority status or minority protection as such.

\section{PROPOSAL OF DEFINITION OF ETHNIC MINORITIES}

Here is an opportunity to answer three questions: 1) why another attempt to define minorities is needed, 2) what is our own proposal of an abstract definition, which would be applicable in most cases, and 3) why our proposal differs from already offered definitions, primarily the Capotorti's definition, which is generally considered to be the best one.

\section{Why One Another Attempt to Define Ethnic (National) Minorities?}

Capotorti's definition was created in the 1970s, at a time when circumstances in both states and the interethnic community were much less favourable for ethnic minorities' protection. On one hand that was Cold War time, when many countries saw potential jeopardy for their own security in ethnic minorities, especially in those whose kin-states were on the other side of the 'Iron Curtain'. ${ }^{2}$ Also, this was the period when human rights were in all aspects far less developed then today. Today, not only we have a whole system of human rights protection both on universal and regional levels. Minority rights are very important part of it. Even more, if in the 1970s when Capotorti proposed his definition majority of states were rejecting any international interference in the respect to if they recognize and how they treat their national minorities, since

1 Contrary to this, one can object that the PCIJ in its Advisory Opinion The Greco-Bulgarian Communities (see supra note 11) concluded on p. 22 that "The existence of communities is a question of fact; it is not a question of law". The same idea we can find in the statement of the former OSCE HCNM in which it is said that the existence of minorities "is a question of fact and not of definition". To support such opinion, the former HCNM quoted the Copenhagen Document (1990) which in para 32 reads: “To belong to a national minority is a matter of a person's individual choice and no disadvantage may arise from the exercise of such choice." The Greco-Bulgarian Communities (1930) Advisory Opinion (see supra note 11); Document of the Copenhagen meeting of the Conference on the Human Dimension of the CSCE (1990) [2018-12-02]. Available at: <www.osce.org/odihr/elections/14304?download=true>; VAN DER STOEL, M. Keynote Address at the CSCE Human Dimension Seminar on "Case Studies on National Minority Issues: Positive Results", Warsaw, 24 May 1993, p. 1 [2018-12-02]. Available at: , <www.osce.org/hcnm/38038?download=true>.

However, one has to remember that the Advisory Opinion not only never has been legally binding document, but it was formulated by judges who, although qualified in the field of International Law, in fact were not experts for minorities and minority rights. To that end one should also not forget that the Advisory Opinion was given some 90 years ago, when the International Law, and particularny protection of minorities were not developed in comparison what we have today. As about the Copenhagen Document it was result of political considerations, something which state representatives have agreed on, but it was not something we can call the scientific truth. Almost the same can be said in respect to the statement of the former HCNM. Even more, his calling on the Copenhagen Document does not seem to be correct, because the Document does not speak of whether the existence of minorities is a question of fact, but instead underlines the importance of a free personal choice, which is something very different. Finally, even the former HCNM himself in the very next paragraph of his statement gave a sort of definition of ethnic minorities.

2 After all, there were still fresh memories of the WW II when some countries, primarily Nazi Germany, used their national minorities in other countries first for various intelligence and undermining activities, and after the taking of these countries as a means of establishing the occupying authority, as a basis for filling the army. 
mid 1990s protection of these groups has been widely recognized as a question of international importance. Inter alia, nowadays we have more and more international documents directly or indirectly concerned with the protection of ethnic (national) minorities. This includes not only the Declaration on the Rights of Persons Belonging to National or Ethnic, Religious and Linguistic Minorities (1992) and the Framework Convention for the Protection of National Minorities (1995), but also the European Charter for Regional or minority Languages (1992), many OSCE and other international organisations documents and, since 1990s, more and more relevant bilateral agreements. In short, the circumstances in which Capotorti and other bestknown proposals ${ }^{1}$ came into existence were very different from those of today. If we focus only on Europe, although there are certain serious problems, almost all European countries are governed by democracies, the former Warsaw treaty members are now members of the European Union and NATO, and so on. Concerning specifically the protection of ethnic minorities, it is sufficient to observe that today are the vast majority of European countries is among members of the most important treaty in this field - the Framework Convention for the Protection of National Minorities (1995). As much as 39 states have ratified the Convention, four have signed it, but have not yet ratified, and only four European countries have neither signed nor ratified the Convention. ${ }^{2}$

\section{Proposal of an Abstract Definition of Ethnic (National) Minorities}

Very important issue, and one of the most important contributions of this paper is a proposal on the new abstract definition of ethnic (national) minorities - the one that would determine these collectives in the narrow sense and would be applicable in most cases.

Recalling the already exposed characteristics of ethnic minorities, as we see them, we believe that an ethnic minority can be spoken of when it is established that there is: (1) a group of nationals, who (2) reside in the territory of the state concerned, (3) possess certain ethnic national, linguistic, religious and similar characteristics, (4) for which it is actually or potentially vulnerable, with the fact that it (5) is not an indigenous people, (6) is sufficiently numerous, although (7) is a numerical minority, which (8) is in the non-dominant position, and which, along with the above (9), expresses, even implicitly, mutual solidarity and the will to preserve its special features.

It is understood, in principle, even more narrow definitions are possible, which would be the consequence of the inclusion of some of here non-mentioned requests - that only so-called autochthonous minorities are recognized, that the relevant minority groups are under the real jurisdiction of the state concerned, that members of the minority live concentrated in a particular area, etc. However, we believe that this would be an excessive narrowing of the notion, primarily for political reasons, and not because of objective needs.

\section{Differences in Comparison with the Capotorti's Definition}

It remains to be answered in what way our approach differs from what has been formulated so far, first of all from the famous and most frequently quoted definition of Capotorti. Taking into account all said above the answer should already be clear.

Firstly, we speak about 'ethnic minorities', which is much wider term then 'national minorities'. As aleady explained, not every 'ethnic minority' is at the same time 'national minority', while every 'national minority' is inevitably 'ethnic minority'.

Secondly, we believe that various definitions for different needs are possible - definition for the needs of a specific country, definitions for the purpose of bilateral agreements, general (abstract) definition for all cases, as well as possible definitions in narrow and wide sense. This is not the case with Capotorti, his definition is formulated for the needs of the UN General Assembly Declaration of the on the rights of national minorities. Moreover, after more than 15 years of work on it, it was not included in this document - the Declaration on the Rights of Persons Belonging to National or Ethnic, Religious and Linguistic Minorities (1992).

Thirdly, if we remain only on the level of the abstract definition, the one in the narrow sense, Capotorti singles out only five elements that make it, requiring that this is a group: 1) numerically inferior to the rest of the population of a State, 2) in a non-dominant position, 3) whose members are nationals of the State, 4) have ethnic, religious or linguistic characteristics differing from those of the rest of the population, and 5) if only implicitly, a sense of solidarity, directed towards the preservation of their culture, traditions, religion or language. We accept all these elements, but expose them in a different order, with somewhat different stylization and some of them illuminated in a slightly different way. This results in the fact that even in this part our definition differs somewhat from the one proposed by Capotorti.

Fourthly, we add as much as four new definition elements, which suggest that one can speak about ethnic minority only when there is a group having not only five above mentioned characteristics (1-5), but which

\footnotetext{
1 Other major proposals came after Capotorti's, but most of them just a few years later, already in the 1980s or at the very beginning of the 1990's.

2 State Parties to the Framework Convention for the Protection of National Minorities, Council of Europe, [2018-12-02]. Available at: <www.coe.int/en/web/minorities/etats-partie>.
} 
is also: (6) sufficiently numerous, (7) located in the territory of the state concerned, (8) actually or potentially vulnerable and (9) which does not represent by itself an indigenous people.

These additional elements represent a difference not only in respect to Capotorti's proposal, but also compared to practically all the other known definitions. We believe that they can help to define more precise necessary frameworks and thus enable the achievement of important goals, which have already been mentioned at the beginning of this paper.

\section{CONCLUSION}

Despite numerous attempts, there is no generally accepted definition of ethnic minorities either in theory or in practice. One can not find it even in international legal documents adopted in Europe, where the protection of ethnic minorities has the longest tradition and is most developed.

It's not just about the theoretical problem, but about the issue that is directly related to the practice. The lack of a precise definition makes relative the intended solutions and opens the way for various types of abuse. This is because it leaves room for everyone to interpret what ethnic minorities are, who belongs to them and thus to whom international standards are to be applied, that is to whom the rights and protection set forth in the relevant international instruments belong.

This suggests that it is better to include the definition of ethnic minorities in international treaties and other international documents on the protection of minorities, even if such definition is not perfect. It is important to point this out now, because it can rightfully be expected that not only new regional agreements on the protection of ethnic minorities will be concluded, but also one can sooner or later expect such a treaty at the universal (world) level.

Starting from the most important characteristics of ethnic minorities, as we see them, in this paper we offered a possible abstract definition, which we believe could be useful in most cases. It is understood, that is just one view of the author and it does not bind anyone. This even more due to the fact that different definitions for various needs are possible. 